UDC 378.147:811.111:81'243(4)

DOI 10.32755/sjeducation.2020.02.150

\title{
AN OVERVIEW ON TEACHING ENGLISH AS A SECOND LANGUAGE TO ADULTS (BASED ON EU EXPERIENCE OF 'IC ENGLISH' PLATFORM)
}

\author{
Nabok Anna, PhD of Philology, \\ Associate Professor Foreign Languages Chair, \\ Academy of the State Penitentiary Service \\ (14000, Ukraine, Chernihiv, Goncha street, 34, \\ e-mail:anna.nabok07@gmail.com) \\ ORCID: 0000-0002-3696-9505 \\ Borysenko Iryna, PhD of Pedagogical Sciences, \\ Head of Foreign Languages Chair, \\ Academy of the State Penitentiary Service \\ (14000, Ukraine, Chernihiv, Goncha street, 34, \\ e-mail: borisenko-irina@ukr.net) \\ ORCID ID 0000-0002-1191-3126
}

Expansive development of the English language throughout the world has recently given it the status of the language of international communication, known as a global language or "lingua franca". The established status of English is strengthened by its dominating in the sphere of politics, mass media, culture, trade and science. Globalization processes accompanied by the expansion of the English language influenced the demand on staff with certain amount of knowledge and skills in the sphere of international communication. Considering the rising need in Englishspeaking employees, there is a need in preparing teachers capable of teaching competitive specialists. Accordingly, it is important to find optimal methods to teach English to adult students.

The article aims at presenting an outline of existing teaching methods to teach English as a second (foreign) language in the view of characterizing basic practices, their development and their influence on adult learners. At the same time the article describes key points of individually-oriented innovative EU educational platform.

In order to achieve the intended objective of the research there was certain methodology applied. Descriptive method let us analyze relevant features of main English teaching methods; historical method helped uncover their developmental peculiarities; comparative method was used to single out their common and different traits in the methodology used in teaching and learning English as a foreign language.

Regarding a method to be a set of procedures, which turn out to be a practical implementation of the chosen approach in a teaching process, the paper reveals different viewpoints on its nature, stresses on hierarchical relations between a method and an approach, and dwells on the major methods having made a considerable impact on the modern English Teaching Methods in EU. Resulting from main 
approaches and methods, a case study of «IC-ENGLISH» platform as an example of an individual approach to teaching adults is presented, whereas four sui generis styles of learning designed by its creators focus on every personality type satisfying their learning needs.

The practical value of the paper lies in the ability to apply the results of the research I teaching English as a second (foreign) language on the basis of the suggested student personality types and according to the devised practical tasks.

Key words: English Teaching Methods, foreign language, method, approach, IC English platform, adult learning types.

\section{АНАЛІЗ МЕТОДІВ НАВЧАННЯ ДОРОСЛИХ АНГЛІЙСЬКОї ЯК ІНОЗЕМНӦ̈ МОВИ (ДОСВІД ЄС ПЛАТФОРМИ 'IC ЕNGLISH')}

Набок Анна Іванівна, кандидат філологічних наук, доцент кафедри іноземних мов, Академія Державної пенітенціарної служби (14000, Україна, м. Чернігів, вуличя Гонча, 34, e-mail:anna.nabok07@gmail.com)

ORCID: 0000-0002-3696-9505

Борисенко Ірина Василівна, кандидат педагогічних наук, доцент, завідувач кафедри іноземних мов, Академія Державної пенітениіарної служби (14000, Україна, м. Чернігів, вулиия Гонча, 34, e-mail: borisenko-irina@ukr.net)

ORCID ID 0000-0002-1191-3126

Експансивний характер розвитку та розповсюдження англійської мови у світі швидко надав їй статусу мови міжнародного спілкування, знаної як глобальної або «linguа franca». Вказане положення англійської мови підкріплюється ї̈ домінуванням у сфері політики, мас-медіа, культури, торгівлі та науки. Глобалізащійні процеси, які супроводжувались широким поступом англійської мови та слугували його причиною, вплинули на попит кадрів з відповідними знаннями у сфері міжнародної комунікаиії. 3 огляду на зростаючу потребу в працівниках, які володіють англійською мовою, на часі є питання підготовки фахівиів, здатних успішно навчати конкурентоздатних спечіалістів. Відповідно, важливим $\epsilon$ пошук оптимальних методів навчання іноземної мови дорослих студентів.

Мета статті. Метою иієї розвідки є огляд та представлення валідних характеристик основних методів навчання англійської як іноземної мови, а також опис ключових орієнтирів індивідуально спрямованої інноваиійної освітньої платформи Свросоюзу, впровадженої sui genеris, з використанням попередніх методологічних здобутків для підвищення результативності у сфері навчання дорослих.

Методи. Для досягнення поставленої мети дослідження було використано дескриптивний метод, який дозволив описати релевантні характеристики 
основних методів навчання англійської як іноземної мови; залучення порівняльно-історичного методу сприяло встановленню їхніх діахронічних закономірностей; порівняльний метод був використаний для виокремлення спільних та відмінних рис у методологічних підходах до навчання та вивчення англійської як іноземної мови.

Результати. У розвідиі запропоновано авторське розуміння методу та підходу у царині викладання англійської як іноземної мови, сформоване з урахуванням наявних дефініиій; виокремлені визначні риси граматичного, прямого, аудіолінгвального методів комунікативного та методу тотальної (повної) фiзичної реакції, закцентована специфіка навчання дорослих англійської як іноземної мови; представлені особливості інноваційного проєкту «IC-ENGLISH».

Практична цінність. Практична иінність статті полягає в можливості застосування прикладних здобутків проєкту «IC-ENGLISH» під час навчання англійської як іноземної мови на основі представленої психотипної диференціації студентів та відповідно розроблених практичних завдань.

Ключові слова: методи викладання англійської мови, іноземна мова, метод, підхід, ІС платформа англійської мови, типи навчання дорослих.

Introduction. This paper presents views and theories on how to teach English as a second (foreign) language to grown-up learners. It presupposes that teaching English as a second language has never been an easy task. While searching for inspiration, principles, very well-known as well as new and original sources to teaching English it is highly important to bear in mind that this is a global language spoken by a vast number of people (native speakers and international communicators), and characterized by a wide geographical distribution. Considered to be a modern «lingua franca» [1, p. 196] as once Latin in the times of the rise of the Roman Empire and the Roman Catholic Church English has developed into the language of international politics and trade. It has successfully occupied media, scientific and educational spheres.

Notwithstanding the continuously growing number of English schools, courses, which make the aim to «learn» the language more tangible, there still exists a constant need for improving English teaching methods [1, p. 363]. In light of the worldwide English language expansion it seems natural to reconsider classic and recent approaches to its teaching methods, which are used to help non native English speakers boost their language skills and integrate into a dominant English-speaking community.

Aims, materials and methods. Following the developing trends of competency-based education, and the focus on a variety of teach- 
ing methods used to present phonological, grammar-lexical, stylistic and text-building material, etc., we have come to believe that there is a need and the aim to present an outline of major English teaching methods, which gave rise to EU innovative teaching project in the field of adult education. The latter stems from the fact that not many English teachers are aware of the history of their profession. Thus they lack information necessary for profound understanding of all linguistic, sociocultural and cognitive backgrounds of origins of their profession and methodological choices they can make.

The application of the descriptive method in the research allowed us to investigate more into the theory of learning and single out key characteristics of different teaching approaches and methodologies. Comparative historical method was used to follow the development and change in the use of methods tried and tested throughout the history of teaching languages to determine the ways of their transformation. Comparative and contrastive types of analysis were involved to find similarities as well as differences in the guiding the process of teaching and learning.

Hence, the paper aims to answer the questions about what a teaching method is; what a teaching approach is; the key features of the approaches and methods used previously and now. It focuses as well on the challenges of teaching English as a second language to adults and strives for finding a successful experience of teaching English in EU to be borrowed and adapted to our circumstances.

Results and discussion. To understand the term "method" it is necessary to reflect on the perspectives of its representation. Naïve points of view on the notion of method are listed in dictionaries. Having considered English-English dictionaries we can conclude that they defined method in a general sense as «a particular way of doing something often that involves a certain system or plan» (Cambridge Dictionary), as «a planned way of doing something, especially one that a lot of people know about and use» (Longman Dictionary, 2014), some definitions being more specific as «a systematic procedure, technique, or mode of inquiry employed by or proper to a particular discipline or art» (Merriam-Webster, 2017).

A scientific perspective of defining a method suggests it is an umbrella term referring to a set of procedures [1, p. 363] and to «the level 
at which theory is put into practice and at which choices are made about the particular skills to be taught, the content to be taught and the order in which the content will be presented» [2, p. 9]. A teaching method refers to a set of teaching procedures that define good practice in language teaching $[2$, p. $19 ; 3$, p. 11]. A teaching method comprises the principles and methods used for instruction. Commonly used teaching methods may include class participation, demonstration, recitation, memorization, or combinations of these [4, p. 2-3]. The choice of teaching method or methods to be used depends largely on the information or skill that is being taught, and it may also be influenced by the aptitude and enthusiasm of the students.

Hence, a teaching method is an overall plan for a systematic presentation of the material. [1, p. 363]. The aim of a teaching method is to present subject matter effectively in a step by step scientific way. A method is defined as a realization of an approach through a certain procedure, referring to the procedure which is included into an approach [4, p. 4]. Therefore any method is said to relate to approach theoretically, and to be put into effect practically within a procedure [5, p. 4].

Methods of teaching include selection, as a teacher always chooses what he is going to teach his students, grading, because it is impossible to supply the whole information at once - a teacher needs to structure the material, choose what to start with, make a certain plan. Presentation of the material is seen as the way the teacher gives the chosen material and interacts with the learners.

When highlighting the similarities and differences between a method and an approach it must be noted that their hierarchical arrangement has been proposed [6, p. 452]. An approach is considered to be a set of correlative assumptions, whereas an approach can include many methods [5, p. 142]. According to Anthony, when deciding on an approach teachers make suppositions and specify beliefs about the process of teaching; method is a chosen way theory is put into practice and at this point teachers decide on how to teach necessary skills, and in what order to present the content. In this way the level of abstraction is explained, approach to be more abstract than a more specific method. Basically, theoreticians of ETMR consider it to be «the theory, philosophy and principles underlying a particular 
set of teaching practices» $[2$, p. 30]. Respectively, approach is a manner of looking at the components of the process of teaching. Underlying any language teaching approach concerns theoretical ideas about the outcome of learning and teaching. Practical application of an approach is seen in methods, described as procedures, which use techniques and classroom to help learners learn [7].

Subsequently, approach refers to theories about the nature of language, its teaching and learning that are prior to the practices and principles of language mastering [8, p. 62]. Certain approach usually leads to a method and this proposal has the advantage of comprehensiveness and simplicity, serving as a useful way of showing the connection between the above mentioned theoretical principles and the practices derived from them.

A long and challenging history of teaching English as a second (foreign) language is subdivided into several basic periods, when a certain method prevailed, being put actively into effect. A glimpse on the basic methods listed below gave rise to the modern ways of teaching English.

Grammar-Translation method suggests teaching grammar, by means of translation from the language learned and back into it respectively [9, p. 294-326]. Thus, the major focus is on reading and writing; no systematic or little attention is paid to speaking or listening. This is the 'classical' or traditional approach to learning a language and it is still commonly used. When this style of teaching is preferred the main idea is to make students learn all grammar rules, in order to translate a number of sentences. Grammar is taught with explanations in the native language; practical application of the rules comes via translating sentences from one language to another. The basic unit of learning and practicing the language is the sentence. Most classes target at phrase translation from one language to another $[2$, p. $5-6 ; 4$, p. $4 ; 8$, p. $63 ; 9$, p. 294-326].

Direct method is a response to the Grammar-Translation method, demonstrating a radical change of the previous teaching aims. Its main concept is that it only uses the target language that the students are learning. It involves the immersion of students in the target language, resembling the way they learned their mother tongue. It is focused on preparing students to use the language in communication 
[2, p. 11-14; 4, p. 5]. All language learning is done in the language you want to learn and mainly oral skill is developed via repetitive drilling. Grammar is taught using an inductive way and students need to try and guess the rules through the teacher's oral presentation. The new vocabulary is taught through demonstration, the emphasis being on speaking and listening with much importance to correct pronunciation. Students must devote much class to oral practice.

The Audio-lingual method satisfies the needs to master oral and aural skills. It is closely connected to behavioral psychology, the elements of repetition and habit formation [8, p. 63]. This method suggests that a learning process should be based on listening and oral production as opposed to writing and reading [2, p. 50-59]. Audiolingual method is related to Direct method as it only uses the target language without translation. The focus of teaching is what makes the Audio lingual method different from the Direct method. The Direct method deals with teaching vocabulary to students whereas the Audio Lingual Method engages specific grammar practice. It presupposes that to learn a language means to master the elements (building blocks) of the language and to learn the grammar rules which help combine these elements at different structural layers of a language, from phoneme to morpheme, word, phrase and sentence $[3$, p. 62-70]. Therefore, the outstanding feature of this method is skills separation (reading, writing, listening and speaking), making audio-lingual primary to graphic skills. The Audio-lingual method uses dialogues as a major means of presenting the language and underlines certain practice techniques especially pattern drills, repetition and so on. Listening and speaking were a major concern in this method, tape recordings, and language laboratory drills were offered in practice. Generally students repeatedly heard different conversations and focus on mimicking the pronunciation and grammatical structures in these dialogues. Vocabulary was taught in context.

The Total Physical Response method was developed and based on the psychological theory that when memory is stimulated by the association the ability to learn a language increases, since there is coordination between speech and action [2, p. 73-75]. This can be observed in learning the language through physical and motor activity. An idea is put forward that direct speech, i.e. "Classroom English", which is 
manifested in teacher's orders produces bodily responses before verbal responses [4, p. 9]. The method is considered to reduce stress and create a positive atmosphere involving playful movements in the process of learning. The teacher uses imperatives, commands, role-playing and games to prepare the students to the situations which may occur in everyday life and places [3, p. 137-145].

Later on, under the influence of philosophy, sociolinguistics and the works of British applied linguists about the functional and communicative characteristics of a language the communicative method was introduced into language teaching [2, p. 153]. It encourages similar to real communication and carry out meaningful tasks, stating that the student has the central role and the teacher acts as a mediator. Showing a supporting role a teacher talks less and listens to his students more, thereby actively fostering student learning [4, p. 157162]. The teacher helps students create meaning, which differs from the aim to drill grammatical structures, acting as an organizer, an analyst, a counselor or a guide, a group process manager. The method is focused on the student ability to acquire the language by focusing on the development of communicative competence. Language learners are expected to be $[8$, p. $69 ; 11$, p. 120].

According to Communicative Language Teaching method, language is used in four competences:

- grammatical competence includes the ability to use the language correctly, operating the rules and features of a new language. This competence is also often called precision;

- discursive competence or fluency lies in the student's ability to speak and write in a new language;

- sociolinguistic competence refers to the student's ability to adequately operate a language in certain social situations;

- strategic competence is defined as a set of strategies for effective communication when the student's vocabulary is insufficient [2, p. $160-163,170-172$; 9, p. 326-330].

Communicative method dominates language teaching in many countries, making language learning more diverse and helping learners develop communicative and linguistic competences.

All the methods mentioned above have contributed to the process of language learning. Having appeared in different historical con- 
texts, they brought to the forefront different social and educational needs and therefore had different aims and manifestations [10, p. 94]. In order the methods to receive effective and efficient practical application teachers should take in mind the age of the learners, their current level of language proficiency, the situations and spheres in which they will be using English in the future, the sort of communicative needs they have [12, p. 343], etc. Respectively, teaching English to adults should differ from teaching it to young learners [13, p. 20]. As it has been proven that under the same conditions adult students become better learners and progress more rapidly than younger learners [5]. However, the initial success of adults could be finally diminished, reducing their chances of acquiring high or expert level status in mastering English.

Adult second language learners' features per se give them excellent chances to study and master their English. Firstly, life experience gained enables them to share it in class and express their opinions on variety of topics. Secondly, their motivation is something real, everyone has their own reasons to engage into the process of learning English, which makes them active participants in class, do their homework and want to learn more [14, p. 58]. Moreover, adults have positive attitudes toward learning and share their thoughts eagerly. They respect their group mates and teachers and are polite with them.

In the light of teaching English as second language to adults the article considers the international project called IC-English Platform It was initiated and created in 2018 by Polish, Czech and Portuguese organizations. It is an innovative project to teach adults second language using digital technologies, which turned out to be an effective means of executing the idea of individual learning. The project focuses on problems which are frequent as far as teaching adults is concerned. Among the problems, arising in the process of teaching English in these EU countries as well as in other countries the main are as follows:

- textbooks overloaded with information but lacking exercises, which makes it difficult to thoroughly practice new material. The reason for it is that textbooks are published in series. However, it is not common for adults to work regularly, finishing one book and starting the next one year after year. They learn in order to satisfy 
their needs and often do not go beyond a B1 level. It means they still have a lot to learn in terms of vocabulary, grammar, writing and speaking after they finish a certain course [15];

- teachers' do not have enough competence in andragogy. They need to adapt their understanding to the skills, needs, motives of grownups, therefore changing their learning options and prerogatives. It springs from the fact that teachers conduct classes often on the analogy with their experience with children, which does not work the same with grownups;

- dealing with grammar will be difficult for those adults, who have low competence as grammar terms, rules and exercises require a linguistic analogy with their native language. Thus, teaching methods should be adopted to meet the demands and the level of adult learners;

- low attendance, as adults work a lot, having their deadlines, business trips, family matters, which distract them from regular learning. This difficulty demands a flexible schedule together with a new multimedia resources, educational platforms and apps to be installed on their smartphones;

- it is challenging for adults to develop their speaking skills apart from using clichés. It should be changed while stimulating situational speaking, that demands certain vocabulary and grammar to be used [15].

To solve the above mentioned problems a group of profound EU experts gathered, involving teachers, psychologists and coaches, specialists in methodology and andragogy; IT specialists, media researchers, etc.

A concept of "IC-ENGLISH" project appeared as a result of collective effort, which included summarizing the advantages of main ETM, and psychological concepts concerning the nature of teaching and learning [15]. Having applied experimental learning cycle by Kolbs, who in his turn uses the concept of Proximal Development Zone by Vygotsky [16, p. 12], the ideologists of "IC-ENGLISH" use the assumption that learning depends on experience rooted in context, as interaction with the knowledge that each individual has already accumulated at a given moment [16]. In other words it is based on experience, reflection, knowledge, application, as a universal method for designing modules for an effective teaching process. 
The advantages of the method created by "IC-ENGLISH" project are that they have designed four unique styles of learning, as a starting point for an individual approach to an adult learner: empiricist, analyst, pragmatist, and theoretician. Thus, the members of the project have singled out main activities for each type of an adult learner.

Such learners' subdivision allows every type of personality to receive education best suited for them. In the following paragraphs a detailed description of the qualities attributed to every type of a learner is given, accompanied by practical activities, which will make their learning process very effective.

The «IC-ENGLISH» approach states that empiricist people learn in the process of doing something. They are open to everything new, to modern techniques, which keep their minds occupied, engaging them fully in new experiences. The activities best suited for them are:

- brainstorming;

- problem solving;

- group discussion;

- puzzles;

- competitions;

- role-play [15].

Theoretician learners are said to better comprehend theory on which the actions are based. They are good at understanding scientific facts, concepts and theoretic models. Theoretician learners easily draw new information into a logical and systematic 'theory', giving preference to analyzing and synthesizing. The methodologists of the project recommend the following activities to them:

- models;

- statistics;

- stories;

- quotes;

- background information;

- applying theories [15].

Pragmatists need to realize the practical value of the information learned. They need to see a way to put the ideas into action in their lives, giving practical application to abstract theoretical concepts and ideas. They often experiment, trying out new ideas, they are ready to 
see if theories and techniques really work. While teaching them tutors should choose:

- time to think about how to apply learning in reality;

- case studies;

- problem solving;

- discussion [15].

Analysts observe and think deeply about what happened, having a deep insight into events and phenomena. They are not spontaneously active and prefer to watch from the sidelines. Analysts view the situation from a number of different perspectives, collecting data and taking the time to work towards an appropriate conclusion. Consequently, they will be good at:

- paired discussions;

- self analysis questionnaires;

- personality questionnaires;

- time out;

- observing activities;

- feedback from others;

- coaching;

- interviews [15].

Having looked into the analysis given, a conclusion can be made that a single learning style seems restrictive. It is necessary to focus on more than a single type of stimulus for the organization of learning activities. While recognizing individuality and the preferences of the subject, providing students with different stimuli, equivalent to the various styles, the project created the most appropriate methodology to the construction of learning.

Moreover, the effectiveness of «IC-ENGLISH» approach is boosted by engaging andragogy, which is adult-oriented unlike pedagogy, being focused on child-learning. According to andragogy assumptions learners know what they need to learn based on selfawareness, they leverage past experiences as a base for the learning process. The learning needs are internal and driven by social roles and responsibilities. Since adult learners are driven by intrinsic factors for learning that are usually connected to their social roles, successful learning challenges are problem-based and connected to realworld situations. 
Conclusions. To conclude, the «IC-ENGLISH» project emphasizes the individuality of the process and the paths chosen by each subject in the construction of knowledge. Students, knowing their learning style can make learning more attractive by prioritizing how they organize their activities and the types of input they are more stimulated by. Teachers are able to recognize that there are different types of adult students and thus ways of learning. The theoretical material in andragogy included into the methodological development of the platform helps prioritize teaching methods and techniques with regard to the motivation and needs of an adult learner, together with the requirements and challenges of the lifelong development of the key competences and basic skills of all EU citizens, regardless of their age.

\section{References}

1. Richards, J. and Schmidt, R. (2010), Longman Dictionary of Language Teaching and Applied Linguistics, 4th ed., Harlow, Pearson Education.

2. Richards, J. and Rodgers, T. (2014), Approaches and methods in language teaching: A description and analysis, 2nd ed., New York, NY, Cambridge University Press.

3. Larsen-Freeman, D. and Anderson M. (2013), Techniques \& Principles in Language Teaching, 3rd ed., Oxford, Oxford University Press.

4. Celce-Murcia, M. (2014), "An overview of Language teaching methods and approaches", in Celce-Murcia, M., Brinton, D., and Snow, M. (Ed.), Teaching English as a Second or Foreign Language, Cengage Learning, pp. 2-14.

5. European Commission (2015), Common European framework of reference for languages: Learning, teaching, assessment, Cambridge, United Kingdom, Cambridge University Press.

6. Stern, H. H. (2001), Fundamental Concepts of Language Teaching, New York, Oxford University Press.

7. 'Approach', available at: https://www.teachingenglish.org.uk /article/approach (accessed 30 October 2020).

8. Harmer, J. (2007), The Practice of English Language Teaching, 4th ed., Pearson, Longman.

9. Howatt, A.P.R. and Widdowson H. G. (2004), A History of English Language Teaching, 2nd ed., Oxford, Oxford University Press.

10. Banciu, V. and Jireghie A. (2012), Communicative Language Teaching. The Public Administration and Social Policies Review. 
11. Farsia, L. (2017), "Re-conceptualizing Communicative Language Teaching through Socio-Cultural Perspective", Englisia, Vol. 3, No. 2, pp. 119-128.

12. Zhao, H. (2016), "Innovation of English teaching methods", Advances in Social Science, Education and Humanities Research, Vol. 85, pp. 343-348.

13. English, L. and Mayo, P. (2012), "Adult education and the state: Gramsci, the historical materialist tradition and relevant others", European Journal for Research on the Education and Learning of Adults, 3 (1), pp. 11-27.

14. McKay H. (2012), Teaching adult second language learners, New York, Cambridge University Press.

15. IC-English Platform, available at: https://ic-english.eu (accessed 30 October 2020).

16. Konak, A., Clark, T. K. and Nasereddin M. (2014), "Using Kolb's Experiential Learning Cycle to improve student learning in virtual computer laboratories", Computers \& Education, Volume 72, pp. 11-22.

17. Moss, D. (2006), Second language acquisition in adults: From research to practice, available at: www.cal.org/caela/esl_resources/digests /SLA.html/ (accessed 30 October 2020).

18. Cambridge Advanced learner's Dictionary, available at: https://dictionary.cambridge.org/dictionary/essential-americanenglish/method.

19. Longman Dictionary of Contemporary English, available at: https://www.ldoceonline.com/dictionary/method.

20. Merriam-Webster Dictionary, available at: https://www.merriamwebster.com/dictionary/method. 